\title{
The Interaction of Calcium-Magnesium-Aluminosilicate with Ytterbium Silicate Environmental Barrier Materials
}

\author{
F. Stolzenburg ${ }^{1 \#}$ M. T. Johnson ${ }^{2}$ K. N. Lee ${ }^{3}$ N. S. Jacobson ${ }^{4}$ and K. T. Faber ${ }^{1,2 \&}$ \\ ${ }^{1}$ Department of Materials Science and Engineering, Northwestern University, \\ Evanston, IL 60208 \\ ${ }^{2}$ Materials Science, California Institute of Technology, Pasadena, CA 91125 \\ ${ }^{3}$ Materials Engineering, Rolls-Royce Corporation, \\ Indianapolis, IN 46241 \\ ${ }^{4}$ NASA Glenn Research Center, Cleveland, OH 44135
}

\begin{abstract}
The interactions of two potential topcoat materials for environmental barrier coatings, $\mathrm{Yb}_{2} \mathrm{SiO}_{5}$ and $\mathrm{Yb}_{2} \mathrm{Si}_{2} \mathrm{O}_{7}$, with calcium-magnesium-aluminosilicate (CMAS) engine deposits were studied. X-ray diffraction, scanning electron microscopy, energy-dispersive X-ray spectroscopy, and electron diffraction were used to investigate the phase transformation associated with the exposure of $\mathrm{Yb}_{2} \mathrm{SiO}_{5}$ and $\mathrm{Yb}_{2} \mathrm{Si}_{2} \mathrm{O}_{7}$ to $\mathrm{CMAS}$ at $1300^{\circ} \mathrm{C}$. It was found that $\mathrm{Yb}_{2} \mathrm{SiO}_{5}$ strongly reacts with CMAS to completely dissolve the $\mathrm{Yb}_{2} \mathrm{SiO}_{5}$ and form hexagonal $\mathrm{Ca}_{2} \mathrm{Yb}_{8}\left(\mathrm{SiO}_{4}\right)_{6} \mathrm{O}_{2}$ deposits. In contrast, no discernable reaction between CMAS and $\mathrm{Yb}_{2} \mathrm{Si}_{2} \mathrm{O}_{7}$, was observed over the 96-hour exposure.
\end{abstract}

Keywords: environmental barrier coating; ceramic; CMAS; X-ray diffraction; energy-dispersive X-ray spectroscopy

\section{INTRODUCTION}

Silicon-based ceramics (i.e., $\mathrm{SiC}, \mathrm{Si}_{3} \mathrm{~N}_{4}$ ) have been identified as some of the most promising materials systems for high-temperature structural applications in engine environments due to

\footnotetext{
\# Current Address: 3M, St. Paul, MN

${ }^{\&}$ Corresponding author: +1-626-395-4448, Fax:+1-626-395-2132; ktfaber@caltech.edu
} 
their low density, excellent high temperature mechanical properties, and good thermomechanical stability. ${ }^{1,2}$ A passivating $\mathrm{SiO}_{2}$ surface layer, which forms on $\mathrm{SiC}$ and $\mathrm{Si}_{3} \mathrm{~N}_{4}$ in oxygen-containing environments, becomes unstable in combustion environments, resulting in the volatilization of the silica layer and component recession. ${ }^{3,4}$ Environmental barrier coatings (EBCs) have been identified as a method of protection from these harsh turbine environments. Important properties of good EBC candidate materials are thermal and phase stability, low volatility in engine environments, a coefficient of thermal expansion (CTE) that matches the underlying layers, and favorable interaction of the active EBC material with environmental deposits, such as molten calcium magnesium aluminosilicates (CMAS).

CMAS interactions with EBCs pose a particularly vexing problem. Molten deposits tend to penetrate open porosity in the coatings and react with traditional EBC chemistries. A three-layer coating system consisting of a silicon bond coat, an intermediate diffusion barrier layer of mullite $\left(3 \mathrm{Al}_{2} \mathrm{O}_{3} \cdot 2 \mathrm{SiO}_{2}\right)$, and a top layer of BSAS, $(1-x) \mathrm{BaO}-x \mathrm{SrO}-\mathrm{Al}_{2} \mathrm{O}_{3}-2 \mathrm{SiO}_{2}$, where $x$ varies between 0 and 1 , has been the most studied system to date. ${ }^{5-10}$ In this system the BSAS acts as the active EBC layer, and the mullite serves as a chemical and oxidation barrier. ${ }^{5,6}$ While these systems have been shown to work well in laboratory-based EBC tests, exposure to molten calcium magnesium aluminosilicate (CMAS) deposits ingested into turbines causes dissolution and reprecipitation of a Ca-modified celsian and cracking in the BSAS topcoat due to interaction between the low-melting CMAS and the topcoat. ${ }^{7-9}$ Additionally, BSAS has been found to react with silica at high temperatures, forming a eutectic with a melting point of $\sim 1300^{\circ} \mathrm{C}$. $^{5,10}$ 
In order to reach significantly higher operating temperatures, new topcoat materials are under development. One promising group of candidate materials is the family of rare-earth silicates. ${ }^{10,11}$ Preliminary studies have shown ytterbium silicates $\left(\mathrm{Yb}_{2} \mathrm{SiO}_{5}\right.$ and $\left.\mathrm{Yb}_{2} \mathrm{Si}_{2} \mathrm{O}_{7}\right)$ to have a good combination of stability in vapor-containing high-temperature environments and structural integrity as part of a multilayer EBC coating. ${ }^{10-13}$ In examination of the stability of hot-pressed $\mathrm{Yb}_{2} \mathrm{SiO}_{5}, \mathrm{Yb}_{2} \mathrm{Si}_{2} \mathrm{O}_{7}$, and BSAS at $1500^{\circ} \mathrm{C}$ in flowing $50 \% \mathrm{H}_{2} \mathrm{O}$-balance $\mathrm{O}_{2}$, the volatility of $\mathrm{Yb}_{2} \mathrm{Si}_{2} \mathrm{O}_{7}$ is comparable to that of BSAS. ${ }^{10,14}$ The silica activity of $\mathrm{Yb}_{2} \mathrm{SiO}_{5^{-}} \mathrm{Yb}_{2} \mathrm{O}_{3}$ and $\mathrm{Y}_{2} \mathrm{SiO}_{5^{-}}$ $\mathrm{Y}_{2} \mathrm{O}_{3}$ biphasic fields is at least two orders of magnitude lower than the silica activity of $\mathrm{Yb}_{2} \mathrm{SiO}_{5^{-}}$ $\mathrm{Yb}_{2} \mathrm{Si}_{2} \mathrm{O}_{7}$ and $\mathrm{Y}_{2} \mathrm{SiO}_{5}-\mathrm{Y}_{2} \mathrm{Si}_{2} \mathrm{O}_{7}$, respectively, ${ }^{15,16}$ explaining the lower volatility of the monosilicates vs. the disilicates, and hence, their attractiveness as EBCs. Volatility alone, however, is not an indicator of resistance to CMAS attack.

Ahlborg and $\mathrm{Zhu}$ studied the reactivity of $\mathrm{Yb}_{2} \mathrm{SiO}_{5}$ and another rare-earth silicate, $\mathrm{Y}_{2} \mathrm{Si}_{2} \mathrm{O}_{7}$, with CMAS at $1300^{\circ} \mathrm{C}$ and $1500^{\circ} \mathrm{C} .{ }^{17}$ They saw very small reaction zones in the $\mathrm{Yb}_{2} \mathrm{SiO}_{5}$ when the interaction studies were performed at $1500^{\circ} \mathrm{C}$; the CMAS fully permeated the $\mathrm{Y}_{2} \mathrm{Si}_{2} \mathrm{O}_{7}$ at the same temperature. Only a glassy surface formed on $\mathrm{Yb}_{2} \mathrm{SiO}_{5}$ at $1300^{\circ} \mathrm{C}$, whereas a silicate oxyapatite, $\mathrm{Ca}_{2} \mathrm{Yb}_{8}\left(\mathrm{SiO}_{4}\right)_{6} \mathrm{O}_{2}$, readily formed in the $\mathrm{Y}_{2} \mathrm{Si}_{2} \mathrm{O}_{7}{ }^{17}$ Grant et al. exposed $\mathrm{Y}_{2} \mathrm{SiO}_{5}$ to CMAS pellets at $1300^{\circ} \mathrm{C}$. They observed significant surface recession and the formation of yttrium silicate oxyapatite $\left(\mathrm{Ca}_{2} \mathrm{Y}_{8}\left(\mathrm{SiO}_{4}\right)_{6} \mathrm{O}_{2}\right)$ crystals. The formation of the silicate oxyapatite and the dissolution of $\mathrm{Y}_{2} \mathrm{SiO}_{5}$ also led to a significant reduction of the Ca concentration in the CMAS and the incorporation of $\sim 10 \mathrm{~mol} \% \mathrm{YO}_{1.5}$ into the glass after 24 hours at $1300^{\circ} \mathrm{C}^{18}$

An alternate strategy for CMAS-resistant coatings has gained attention for thermal barrier coatings (TBC) systems. Strong reactivity between CMAS and the EBC to form stable 
crystalline phases may be helpful in mitigating the advance of molten CMAS; rare-earth zirconates rely on this mechanism to slow down the advance of CMAS through the coating to underlying TBC. ${ }^{19}$ Part of the effectiveness of the rare-earth zirconates can be found in their ability to limit the size of the reaction zone. In a recent study by Poerschke and Levi on rareearth containing zirconates and halfnates, they discerned that the size of the rare-earth element determined the effectiveness of the reaction. ${ }^{20}$ As a guide for the development of optimal coating, larger rare-earth elements proved most successful. Unfortunately, because the zirconates have relatively high coefficients of thermal expansion, they are not suited for siliconbased ceramic-EBC systems, but rather for superalloy-TBC systems.

In this study, the interaction of both $\mathrm{Yb}_{2} \mathrm{Si}_{2} \mathrm{O}_{7}$ and $\mathrm{Yb}_{2} \mathrm{SiO}_{5}$ with CMAS was investigated in more detail using lab-based X-ray diffraction, SEM, EDS, quantitative phase analysis reference intensity ratio (RIR) methods, and selected area electron diffraction (SAED). To our knowledge, this is the first study that compares the reactivity of $\mathrm{Yb}_{2} \mathrm{SiO}_{5}$ and $\mathrm{Yb}_{2} \mathrm{Si}_{2} \mathrm{O}_{7}$ with $\mathrm{CMAS}$ under identical conditions. Of particular interest is the contrast in the ease of formation of silicate oxyapatite $\left(\mathrm{Ca}_{2} \mathrm{Yb}_{8}\left(\mathrm{SiO}_{4}\right)_{6} \mathrm{O}_{2}\right)$ in the two systems, and whether its formation could provide a reaction zone of limited thickness which would preclude further CMAS-coating reaction.

\section{EXPERIMENTAL PROCEDURE}

\subsection{Processing and Sample Preparation}

The CMAS glass with a $33 \mathrm{CaO}-9 \mathrm{MgO}-13 \mathrm{AlO}_{1.5}-45 \mathrm{SiO}_{2}$ composition was prepared by mixing $\mathrm{Al}_{2} \mathrm{O}_{3}$ (Praxair, Danbury, CT), $\mathrm{CaO}$ (Aldrich, St. Louis, MO), MgO (Alfa Aesar, Ward Hill, MA), and $\mathrm{SiO}_{2}$ (Alfa Aesar). The mixed powders were wet milled in water using $\mathrm{Al}_{2} \mathrm{O}_{3}$ media 
for 24 hours. The milled mixture was heated for 4 hours at $1550^{\circ} \mathrm{C}$ in a platinum crucible in air, ground with a mortar and pestle, and heated to $1550^{\circ} \mathrm{C}$ for 4 hours again. The glass was then removed from the crucible and ground to a fine powder (particle size below $50 \mu \mathrm{m}$ ). The $33 \mathrm{CaO}-$ $9 \mathrm{MgO}-13 \mathrm{AlO}_{1.5}-45 \mathrm{SiO}_{2}$ composition used in this study with a melting point of $\sim 1230^{\circ} \mathrm{C}$, is a composition eften used in prior studies, ${ }^{7,18,19}$ a version of CMAS first described by Borom et al. ${ }^{21}$

To study the interaction between CMAS and $\mathrm{Yb}_{2} \mathrm{SiO}_{5}$ and $\mathrm{Yb}_{2} \mathrm{Si}_{2} \mathrm{O}_{7}$ powders (Treibacher, Austria), $70 \mathrm{wt} \%$ phase-pure fully crystalline ytterbium silicate (either mono- or di-) and $30 \mathrm{wt} \%$ CMAS powders were finely ground together using mortar and pestle. After careful mixing, the samples were heated in a platinum crucible at $1300^{\circ} \mathrm{C}$ in air for times of 1 minute, 4 hours, 24 hours, and 96 hours to ensure complete melting of the CMAS. Upon removal from the furnace, the material was ground finely again with a mortar and pestle and then mixed with fully crystalline $\mathrm{Al}_{2} \mathrm{O}_{3}$ for reference intensity ratio (RIR) analysis.

To study of the behavior of the ytterbium silicate/CMAS reaction interfaces in greater detail, bulk $\mathrm{Yb}_{2} \mathrm{SiO}_{5}$ and $\mathrm{Yb}_{2} \mathrm{Si}_{2} \mathrm{O}_{7}$ samples were exposed to CMAS at elevated temperature. The exposure to CMAS was achieved by drilling wells $1.5 \mathrm{~mm}$ in diameter and $1.2 \mathrm{~mm}$ deep into bulk $\mathrm{Yb}_{2} \mathrm{SiO}_{5}$ and $\mathrm{Yb}_{2} \mathrm{Si}_{2} \mathrm{O}_{7}$ samples using an ultrasonic drill press. The dimensions were chosen such that complete filling of the well with CMAS resulted in a loading of $35 \mathrm{mg} / \mathrm{cm}^{2}$, an average for all surfaces including the sidewalls. Due to the melting of the CMAS this will lead to locally much higher loadings than are likely seen in real EBC systems. After filling the holes with CMAS, the samples were then heated to $1300^{\circ} \mathrm{C}$ in air for 1 minute, 4 hours, 24 hours, and 96 hours. 


\subsection{Quantitative Phase Analysis Using RIR}

Quantitative X-ray phase analysis was performed with the reference intensity ratio methodology (RIR). RIR allows for the quantification of crystalline and amorphous weight fractions for known phases in powdered samples by comparing the relative intensities of crystalline peaks of the phases of interest to the intensity of a standard, in this case, the (113) peak of corundum $\left(\mathrm{Al}_{2} \mathrm{O}_{3}\right)$, of which $50 \mathrm{wt} \%$ was mixed into the sample prior to the X-ray measurement. This method is described in more detail by Prevey, et al., who used it to study the crystallization of plasma-sprayed hydroxyapatite coatings for medical implants. ${ }^{22}$

All measurements for reference intensity ratios in this study were performed on a Rigaku 9400 -2 $2 \theta$ diffractometer at the Northwestern University’s Jerome B. Cohen X-ray Facility. The instrument utilizes $\mathrm{Cu}$ radiation $\left(\mathrm{K}_{\alpha}, 1.54 \AA\right.$ ) , a $0.5^{\circ}$ divergence and a $0.5^{\circ}$ Soller slit, a receiving slit of $0.15 \mathrm{~mm}$, and a Ni filter to block out $\mathrm{Cu} \mathrm{K}_{\beta}$ radiation. The small slit sizes were chosen due to the quantitative nature of the experiments. These very small slits minimized the diffracted intensities of the powder samples while maximizing the resolution of the diffractometer. To increase the diffracted intensities, a two-second dwell was taken at each $0.02^{\circ}$ step from $20^{\circ}-70^{\circ}$, leading to a total measurement time of 90 minutes for each scan.

To establish the RIR for $\mathrm{Yb}_{2} \mathrm{SiO}_{5}$ and $\mathrm{Yb}_{2} \mathrm{Si}_{2} \mathrm{O}_{7}$, about 10 grams of each phase-pure, fully crystalline powder were mixed with the same mass of phase-pure, fully crystalline $\mathrm{Al}_{2} \mathrm{O}_{3}($ Fisher Scientific). To ensure that all materials were phase pure and fully crystalline, X-ray scans were performed on all materials separately before mixing. The corundum was heat-treated at $1400^{\circ} \mathrm{C}$ 
for $4 \mathrm{~h}$ because it was partially amorphous upon delivery. No amorphous background could be observed in the corundum after the heat treatment.

The powders were weighed, mixed, and ground together with a mortar and pestle. Approximately $200 \mathrm{mg}$ of powder was then placed on amorphous $\mathrm{SiO}_{2} \mathrm{X}$-ray slides to be used in the diffractometer. Each measurement was repeated five times with powder from the same batch to ensure that incomplete mixing did not contribute significantly to the measured RIRs. Table I summarizes the RIRs that were determined for this work. The integrated intensity of the most intense peak in the spectrum was used for the intensity integration necessary for RIR analysis as maximizing intensity increased the accuracy of this methodology.

In order to evaluate the experimental error associated with using RIR on the Rigaku 9400, a series of experiments was performed on powders of several known mixtures of $\mathrm{Yb}_{2} \mathrm{Si}_{2} \mathrm{O}_{7}, \mathrm{Yb}_{2} \mathrm{O}_{3}$, $\mathrm{Yb}_{2} \mathrm{SiO}_{5}$, and amorphous $\mathrm{SiO}_{2}$. During this series of experiments it was determined that the magnitude of experimental error of this methodology as used in this paper was approximately $2.5 \mathrm{wt} \%$.

\subsection{Analysis of Bulk Ytterbium Silicate/CMAS Sample Interfaces}

After the heat treatments, the bulk ytterbium silicate samples with the filled CMAS wells were cross-sectioned and polished for SEM imaging and energy-dispersive X-ray spectroscopy (EDS) using a Hitachi S3400N-II SEM (Northridge, CA) and Zeiss 1550VP FESEM (Jena, Germany), both equipped with Oxford SDD EDS detectors (Concord, MA). After the EDS analysis was completed, TEM specimens, $12 \mu \mathrm{m}$ wide, $6 \mu \mathrm{m}$ long, and $100 \mathrm{~nm}$ thick, were prepared with an FEI Helios Nanolab Dual Beam SEM/FIB (Hillsboro, OR). Electron diffraction on FIB samples 
was then performed on a Hitachi H-8100 TEM at an energy of $200 \mathrm{keV}$. A double-tilt holder was used to allow for proper rotation of the sample relative to the beam.

\section{RESULTS}

\subsection{CMAS interaction with $\mathrm{Yb}_{2} \mathrm{SiO}_{5}$}

The weight fraction of crystalline $\mathrm{Yb}_{2} \mathrm{SiO}_{5}$ as a function of heat treatment time at $1300^{\circ} \mathrm{C}$ of a $70 \mathrm{wt} \% \mathrm{Yb}_{2} \mathrm{SiO}_{5} / 30 \mathrm{wt} \% \mathrm{CMAS}$ sample is shown in Figure 1. The crystalline phase fraction was determined using RIR. The graph shows that the crystalline fraction of $\mathrm{Yb}_{2} \mathrm{SiO}_{5}$ decreased rapidly upon exposure to $\mathrm{CMAS}$ at $1300^{\circ} \mathrm{C}$. While the $\mathrm{Yb}_{2} \mathrm{SiO}_{5}$ was fully crystalline at the start of the high temperature exposure, a one-minute exposure to CMAS decreased that fraction to only $27 \%$, while only about $7 \%$ crystalline $\mathrm{Yb}_{2} \mathrm{SiO}_{5}$ could be found in the samples after 96 hours.

Looking at the X-ray diffraction patterns in Figure 2 comparing the as-mixed and heated samples, there are two noteworthy items. First, all the $\mathrm{Yb}_{2} \mathrm{SiO}_{5}$ peaks that were present in the asmixed sample have disappeared almost completely. The second observation is that many strong new peaks have formed, indicating the formation of at least one new crystalline phase. The strongest peak of this new phase can be seen at $32^{\circ} 2 \theta$, with other strong peaks at $28^{\circ}$ and $33^{\circ} 2 \theta$. Figure $2 \mathrm{~b}$ shows an enlarged view of the region from $25^{\circ}$ to $35^{\circ} 2 \theta$ to illustrate the changes in the diffraction patterns. The best match for this diffraction pattern was $\mathrm{Ca}_{2} \mathrm{Yb}_{8}\left(\mathrm{SiO}_{4}\right)_{6} \mathrm{O}_{2}$, a hexagonal silicate oxyapatite. This is the ytterbium-containing equivalent of the apatite phase that has been observed in the interaction of CMAS with yttrium silicates and rare-earth

zirconates. ${ }^{18,23}$ All the peaks in the diffraction pattern of the heat-treated sample can be attributed to the silicate oxyapatite. However, the observed relative intensities of the silicate oxyapatite 
phase vary significantly from those found in the literature (ICDD PDF 04-006-0320). To confirm that the precipitate phase was indeed the silicate oxyapatite, further SEM, EDS and electron diffraction analysis was performed.

Figure 3 shows an SEM image of one of the $70 \mathrm{wt} \% \mathrm{Yb}_{2} \mathrm{SiO}_{5} / \mathrm{CMAS}$ powder samples. The majority of the volume in the heat-treated sample is now comprised of hexagonal precipitates. Since it is known that the shape of a crystal is often closely related to its crystal structure, this phase likely possesses a hexagonal crystal structure consistent with the silicate oxyapatite. ${ }^{24}$

The hexagonal structures can also be seen in the SEM image of the bulk $\mathrm{Yb}_{2} \mathrm{SiO}_{5}$ sample exposed to molten CMAS at $1300^{\circ} \mathrm{C}$ for 4 hours (Figure 4a). This image confirms that CMAS and $\mathrm{Yb}_{2} \mathrm{SiO}_{5}$ interacted strongly to form a new phase incorporating ytterbium from the bulk $\mathrm{Yb}_{2} \mathrm{SiO}_{5}$. EDS analysis was performed on the precipitates and the glass phase (the dark gray phase in Figure 4a) to determine their approximate compositional information. EDS element maps for $\mathrm{Ca}, \mathrm{Si}$, and $\mathrm{Yb}$ can be seen in Figure $4 \mathrm{~b}$. The new phase that formed was similar in contrast to the $\mathrm{Yb}_{2} \mathrm{SiO}_{5}$, indicating a high fraction of $\mathrm{Yb}$. The inset in Figure $4 \mathrm{c}$ is an SAED pattern of one of the precipitates.

The EDS analysis confirmed that the needles contained a large fraction of $\mathrm{Yb}$, while the surrounding matrix phase was closer in composition to the original CMAS glass. The needles also contained much less calcium and silicon than the CMAS phase. The same analysis was also performed on the needles using point scans. An average of compositional results collected in the 
needles and the glass approximately $100 \mu \mathrm{m}$ from the $\mathrm{CMAS} / \mathrm{Yb}_{2} \mathrm{SiO}_{5}$ interface are summarized in Table II.

While the original CMAS composition was $33 \mathrm{CaO}-9 \mathrm{MgO}-13 \mathrm{AlO}_{1.5}-45 \mathrm{SiO}_{2}$, the composition of the glass in this sample was $22.9 \mathrm{CaO}-9.8 \mathrm{MgO}-12.9 \mathrm{AlO}_{1.5}-6.4 \mathrm{YbO}_{1.5}-48 \mathrm{SiO}_{2}$. Some of the calcium from the CMAS has been incorporated into the needle-like precipitates, leading to a reduction in the calcium content in the glass. CMAS has long been known to dissolve EBC and TBC materials, explaining the dissolution of $\mathrm{Yb}_{2} \mathrm{SiO}_{5}$ into the CMAS. ${ }^{7,18,19,23,25-29}$ The composition of the $\mathrm{Ca}_{2} \mathrm{Yb}_{8}\left(\mathrm{SiO}_{4}\right)_{6} \mathrm{O}_{2}$ silicate oxyapatite phase based on its formula is $12.5 \mathrm{~mol} \%$ $\mathrm{Ca}, 37.5 \mathrm{~mol} \% \mathrm{Si}$, and $50 \mathrm{~mol} \% \mathrm{Yb}$. The composition of the precipitates as determined with EDS was very close to the theoretical composition of the silicate oxyapatite phase. An electron diffraction pattern of one of the needle-like precipitates is shown in Figure $5 \mathrm{c}$ and is consistent with the $\mathrm{Ca}_{2} \mathrm{Yb}_{8}\left(\mathrm{SiO}_{4}\right)_{6} \mathrm{O}_{2}$ compound.

\subsection{CMAS interaction with $\mathrm{Yb}_{2} \mathrm{Si}_{2} \mathrm{O}_{7}$}

The results of the powder interaction study between CMAS and $\mathrm{Yb}_{2} \mathrm{Si}_{2} \mathrm{O}_{7}$ powders also are shown in Figure 1. After up to 4 hours at $1300^{\circ} \mathrm{C}$, the CMAS has not decreased the crystalline fraction of $\mathrm{Yb}_{2} \mathrm{Si}_{2} \mathrm{O}_{7}$ measurably. After 48 hours, however, the CMAS has started to dissolve the $\mathrm{Yb}_{2} \mathrm{Si}_{2} \mathrm{O}_{7}$, but the reaction rate of the disilicate is significantly slower than that of the monosilicate (by approximately one order of magnitude). By 96 hours, the crystalline phase fraction of $\mathrm{Yb}_{2} \mathrm{Si}_{2} \mathrm{O}_{7}$ has been reduced by $30 \%$. However, no new peaks have appeared in the X-ray diffraction pattern, seen in Figure 5. In the enlarged view of the diffraction pattern from $25^{\circ}$ to $35^{\circ} 2 \theta$ in Figure $5 \mathrm{~b}$, the intensity of the $\mathrm{Al}_{2} \mathrm{O}_{3}$ standard is shown to increase, indicative of diminishing crystalline $\mathrm{Yb}_{2} \mathrm{Si}_{2} \mathrm{O}_{7}$ fraction. The spectrum is marked by $*$ which refer to the 
expected positions of $\mathrm{Ca}_{2} \mathrm{Yb}_{8}\left(\mathrm{SiO}_{4}\right)_{6} \mathrm{O}_{2}$ reflections where none exists. We conclude that after 96 hours at $1300^{\circ} \mathrm{C}$ some dissolution of the $\mathrm{Yb}_{2} \mathrm{Si}_{2} \mathrm{O}_{7}$ occurs. However, the reaction to form $\mathrm{Ca}_{2} \mathrm{Yb}_{8}\left(\mathrm{SiO}_{4}\right)_{6} \mathrm{O}_{2}$, even with high surface area powders, does not occur to any quantifiable extent.

An SEM image from the $\mathrm{Yb}_{2} \mathrm{Si}_{2} \mathrm{O}_{7}$ sample heated to $1300^{\circ} \mathrm{C}$ for 96 hours with a CMAS-filled well is shown in Figure 6a. Although CMAS has penetrated the $\mathrm{Yb}_{2} \mathrm{Si}_{2} \mathrm{O}_{7}$, which has approximately $10 \%$ porosity, no extensive reaction layer is observed, in contrast to the $\mathrm{CMAS} / \mathrm{Yb}_{2} \mathrm{SiO}_{5}$ well test. EDS results taken from 10 points approximately $20 \mu \mathrm{m}$ from the well surface indicate a composition of $45 \mathrm{~mol} \% \mathrm{Yb}$ and $55 \mathrm{~mol} \% \mathrm{Si}$ oxide vs. the stoichiometric compound (50 mol\% Yb, $50 \mathrm{~mol} \% \mathrm{Si}$ ), within experimental error.

Isolated $\mathrm{Ca}_{2} \mathrm{Yb}_{8}\left(\mathrm{SiO}_{4}\right)_{6} \mathrm{O}_{2}$ particles were identified closer to the well, to a depth of $\sim 1 \mathrm{~mm}$. These are attributed to minor amounts of $\mathrm{Yb}_{2} \mathrm{SiO}_{5}$ (less than $1.5 \mathrm{wt} \%$ ) in the disilicate sample which react with the CMAS. Figure $6 \mathrm{~b}$ reveals this transition. In Figure $6 \mathrm{c}$, light gray features have been identified by EDS as $\mathrm{Ca}_{2} \mathrm{Yb}_{8}\left(\mathrm{SiO}_{4}\right)_{6} \mathrm{O}_{2}$ near the well, while the white features in Figure 6d, near the outer sample edge, are unreacted $\mathrm{Yb}_{2} \mathrm{SiO}_{5}$. Although Ca-containing oxyapatite phases were identified, residual $\mathrm{Mg}$ or $\mathrm{Al}$ were not evident, likely indicating any unreacted CMAS species are in the form of a thin surface glass along pore walls and grain boundaries in quantities below EDS detection limits.

\section{DISCUSSION}

$\mathrm{Yb}_{2} \mathrm{SiO}_{5}$ was found to interact very strongly with molten CMAS, leading to the complete dissolution of $\mathrm{Yb}_{2} \mathrm{SiO}_{5}$ powders in the presence of molten CMAS. A combination of XRD, SEM, 
EDS, and electron diffraction prove that a crystalline phase is formed upon the dissolution of $\mathrm{Yb}_{2} \mathrm{SiO}_{5}$ at $1300^{\circ} \mathrm{C}$. The phase was determined to be $\mathrm{Ca}_{2} \mathrm{Yb}_{8}\left(\mathrm{SiO}_{4}\right)_{6} \mathrm{O}_{2}$, a silicate oxyapatite. The formation of this phase has been documented in other rare-earth containing EBC and TBC compounds. However our studies indicate a rapid reaction, as shown by both the complete dissolution of ground $\mathrm{Yb}_{2} \mathrm{SiO}_{5}$ powders after short high-temperature exposures to molten CMAS and a $300 \mu \mathrm{m}$ thick interaction zone at the $\mathrm{CMAS} / \mathrm{Yb}_{2} \mathrm{SiO}_{5}$ interface in only four hours.

While the $\mathrm{Yb}_{2} \mathrm{SiO}_{5}$ reaction, shown in Figure 3, demonstrates the propensity for dissolution in CMAS and precipitation of the silicate oxyapatite, little or no reaction occurs with $\mathrm{Yb}_{2} \mathrm{Si}_{2} \mathrm{O}_{7}$. The presence of CMAS did decrease the crystalline volume fraction of $\mathrm{Yb}_{2} \mathrm{Si}_{2} \mathrm{O}_{7}$ powders by approximately $30 \%$ within 96 hours at $1300^{\circ} \mathrm{C}$. However, there was no obvious formation of a secondary phase for the $\mathrm{Yb}_{2} \mathrm{Si}_{2} \mathrm{O}_{7}$ powder or well sample.

To our knowledge, no thermodynamic data exist to provide insight as to why the silicate oxyapatite reaction is favored in the $\mathrm{Yb}_{2} \mathrm{SiO}_{5}$ over the $\mathrm{Yb}_{2} \mathrm{Si}_{2} \mathrm{O}_{7}$ at temperatures of $1300^{\circ} \mathrm{C}$. However, the difference in reactivity might be attributed to the difference in $\mathrm{Yb}_{2} \mathrm{O}_{3}$ thermodynamic activity between the $\mathrm{Yb}_{2} \mathrm{SiO}_{5}$ and $\mathrm{Yb}_{2} \mathrm{Si}_{2} \mathrm{O}_{7}$. Based upon the work of Costa and Jacobson ${ }^{16}$, Figure 7 demonstrates that the $\mathrm{Yb}_{2} \mathrm{SiO}_{5}$ has a higher $\mathrm{Yb}_{2} \mathrm{O}_{3}$ activity than the $\mathrm{Yb}_{2} \mathrm{Si}_{2} \mathrm{O}_{7}$ by more than three orders of magnitude. Therefore, the $\mathrm{Yb}_{2} \mathrm{SiO}_{5}$ should react more readily to form the silicate oxyapatite than $\mathrm{Yb}_{2} \mathrm{Si}_{2} \mathrm{O}_{7}$. There are also many other factors that influence the relative reactivity of the $\mathrm{Yb}_{2} \mathrm{SiO}_{5}$ and $\mathrm{Yb}_{2} \mathrm{Si}_{2} \mathrm{O}_{7}$ such as thermodynamic stability of the formed silicate oxyapatite phase and degree of crystallinity of products and reactants. These factors may explain the reported high reactivity of $\mathrm{Y}_{2} \mathrm{Si}_{2} \mathrm{O}_{7}$ with CMAS by Ahlborg and Zhu, 
which is in contrast to the observations reported here for $\mathrm{Yb}_{2} \mathrm{Si}_{2} \mathrm{O}_{7}$ and CMAS. ${ }^{18}$ This is discussed in more detail below.

In their study of the interaction between $\mathrm{Y}_{2} \mathrm{SiO}_{5}$ and CMAS Grant et al. use mass balance to speculate that $\mathrm{Y}_{2} \mathrm{SiO}_{5}$ should be expected to assuage CMAS attack through the formation of $\mathrm{Ca}_{2} \mathrm{Yb}_{8}\left(\mathrm{SiO}_{4}\right)_{6} \mathrm{O}_{2}$ better than the corresponding disilicate. ${ }^{18}$ This is due to the fact that, for equivalent CMAS loadings, more disilicate on a per mole basis, is required to form the silicate oxyapatite than the monosilicate. An analogous argument should hold for Yb-silicates, but this neglects the change in composition of the CMAS on formation of the silicate oxyapatite. In the current study, when reacting $70 \mathrm{wt} \%$ monosilicate with $30 \mathrm{wt} \%$ CMAS, there is more than enough calcium to complete the reaction to form $\mathrm{Ca}_{2} \mathrm{Yb}_{8}\left(\mathrm{SiO}_{4}\right)_{6} \mathrm{O}_{2}$. The final glass composition if the reaction proceeds completely is $26 \mathrm{CaO}-13 \mathrm{MgO}-18 \mathrm{AlO}_{1.5}-43 \mathrm{SiO}_{2}$, which is not substantially different than the EDS findings in the well experiment (Table II). In the well experiment, the monosilcate is dissolved, calcium is removed from the CMAS, and reprecipitates as the silicate oxyapatite, while the amount of silica in melt virtually unchanged. In comparison, when reacting $70 \mathrm{wt} \%$ disilicate with $30 \mathrm{wt} \% \mathrm{CMAS}$, there is again more than enough calcium to complete the reaction. However, the final glass composition if the reaction were to proceed completely is $20 \mathrm{CaO}-9 \mathrm{MgO}-13 \mathrm{AlO}_{1.5}-58 \mathrm{SiO}_{2}$, substantially increasing the amount of silica to the melt. The partial dissolution of the disilicate is documented in Figure 1. It may be that the excess silica in the melt approaches saturation and limits further reaction. Furthermore, higher concentrations of silica are bound to have a large effect on the viscosity of and diffusivity in the CMAS. In any event, a mass balance argument alone says nothing about relative solubilities of the monosilicate vs. the disilicate in CMAS, or about reaction rates. 
Confounding study-to-study comparisons of rare-earth silicate coatings are two factors. First, plasma spray powders in general are known to contain residual unreacted constituent oxides. The degree of phase purity is also dependent upon the coating processing method. It is not uncommon, for example, to find amorphous materials in plasma-sprayed coatings in the assprayed state. Certainly the degree of crystallization will influence the degree of reactivity. In the present study, we were careful to use only phase pure powders for the RIR studies. Second, the composition of the CMAS is also likely to influence dissolution and reprecipitation. The CMAS used in the Ahlborg and Zhu study contained minor amounts of $\mathrm{Fe}_{2} \mathrm{O}_{3}$ and $\mathrm{NiO},{ }^{17}$ while the current study used the composition of Grant et al. ${ }^{18}$ Another significant and poorly understood factor influencing the reaction between $\mathrm{Yb}_{2} \mathrm{SiO}_{5}$ and CMAS is the thermal stability of CMAS and reaction products at elevated temperatures. While CMAS is stable at $1300^{\circ} \mathrm{C}$, Ahlborg et al. noted that it readily evaporates at $1500{ }^{\circ} \mathrm{C} .{ }^{17}$ To date, no detailed thermogravimetric analysis of CMAS has been reported, making it impossible to say exactly what influence the stability of CMAS has on the performance of EBCs.

Finally, regarding an analogous solution to rare-earth zirconate-TBC strategy where a fast reaction and thin reaction layer, mitigates CMAS attack, the $\mathrm{CMAS} / \mathrm{Yb}_{2} \mathrm{SiO}_{5}$ interaction zone was found to be much too thick, $\sim 300 \mu \mathrm{m}$ thick after only 4 hours. This likely precludes the use of $\mathrm{Yb}_{2} \mathrm{SiO}_{5}$ in CMAS-containing environments. Although the much better resistance to CMAS attack when compared to $\mathrm{Yb}_{2} \mathrm{SiO}_{5}$ makes $\mathrm{Yb}_{2} \mathrm{Si}_{2} \mathrm{O}_{7}$ a more promising topcoat material, the penetration along grain boundaries of the $\mathrm{Yb}_{2} \mathrm{Si}_{2} \mathrm{O}_{7}$ to underlying layers could prove problematic. 


\section{SUMMARY AND CONCLUSIONS}

The interaction of two potential environmental barrier coating materials, $\mathrm{Yb}_{2} \mathrm{SiO}_{5}$ and $\mathrm{Yb}_{2} \mathrm{Si}_{2} \mathrm{O}_{7}$, with molten CMAS was studied in detail using a combination of X-ray diffraction, scanning electron microscopy, and electron diffraction. The reactivity of the two ytterbium silicates with CMAS was strikingly different, and might be ascribed to the fact that $\mathrm{Yb}_{2} \mathrm{SiO}_{5}$ has a higher $\mathrm{Yb}_{2} \mathrm{O}_{3}$ activity than the $\mathrm{Yb}_{2} \mathrm{Si}_{2} \mathrm{O}_{7}$ by more than three orders of magnitude. A sample with 30 wt $\%$ molten CMAS was shown to dissolve $\mathrm{Yb}_{2} \mathrm{SiO}_{5}$ almost completely within an hour and cause the formation of large, hexagonal, needle-like precipitates. These precipitates were shown to be $\mathrm{Ca}_{2} \mathrm{Yb}_{8}\left(\mathrm{SiO}_{4}\right)_{6} \mathrm{O}_{2}$. The strong interaction of $\mathrm{Yb}_{2} \mathrm{SiO}_{5}$ with CMAS puts its usefulness as an environmental barrier coating into doubt.

Dissolution of $\mathrm{Yb}_{2} \mathrm{Si}_{2} \mathrm{O}_{7}$ powders with CMAS was found to proceed much more slowly than with $\mathrm{Yb}_{2} \mathrm{SiO}_{5}$. In a powder sample of $30 \mathrm{wt} \% \mathrm{CMAS}$ and $\mathrm{Yb}_{2} \mathrm{Si}_{2} \mathrm{O}_{7}$ only about a third of the $\mathrm{Yb}_{2} \mathrm{Si}_{2} \mathrm{O}_{7}$ dissolved after a 96 -hour exposure to molten CMAS at $1300^{\circ} \mathrm{C}$. Its lower reactivity with CMAS makes $\mathrm{Yb}_{2} \mathrm{Si}_{2} \mathrm{O}_{7}$ a better candidate for an EBC topcoat material, provided that the underlying layer is also resistant to CMAS reaction should CMAS penetrate along $\mathrm{Yb}_{2} \mathrm{Si}_{2} \mathrm{O}_{7}$ grain boundaries.

\section{Acknowledgements}

This research was made possible by the Advanced Photon Source, a U.S. Department of Energy (DOE) Office of Science User Facility operated for the DOE Office of Science by Argonne National Laboratory under Contract No. DE-AC02-06CH11357. This work made use of the OMM Facility supported by the MRSEC program of the National Science Foundation (DMR1121262) at the Materials Research Center of Northwestern University. SEM and FIB-SEM 
(FEI) were performed in the EPIC facility of NUANCE Center at Northwestern University.

NUANCE Center is supported by NSF-NSEC, NSF-MRSEC, Keck Foundation, the State of Illinois, and Northwestern University. X-Ray diffraction experiments were performed at the Cohen X-ray Lab at Northwestern University. The Cohen X-ray Facility is supported by NSFMRSEC. A Northwestern University Terminal Year Fellowship provided partial support for F.S. 


\section{REFERENCES}

[1] E.J. Opila, J.L. Smialek, R.C. Robinson, D.S. Fox, N.S. Jacobson, SiC recession caused by $\mathrm{SiO}_{2}$ scale volatility under combustion conditions: II, thermodynamics and gaseous-diffusion model, J. Am. Ceram. Soc. 82 (1999) 1826-1834.

[2] K.N. Lee, Current status of environmental barrier coatings development for Si-based ceramics, Surf. Coat. Technol. (2000) 133-134.

[3] E.J. Opila, Oxidation and volatilization of silica formers in water vapor, J. Am. Ceram. Soc. $86(2003)$ 1238-1248.

[4] E.J. Opila, R.E. Hann, Paralinear oxidation of CVD SiC in water vapor, J. Am. Ceram. Soc. 80 (1997) 197-205.

[5] K.N. Lee, D.S. Fox, J.I. Elridge, D. Zhu, R.C. Robinson, N.P. Bansal, R.A. Miller, Upper temperature limit of environmental barrier coatings based on mullite and BSAS, J. Am. Ceram. Soc. 86 (2003) 1299-1306.

[6] K.N. Lee, Key durability issues with mullite-based environmental barrier coatings for Sibased ceramics, J. Eng. Gas Turb. Power 122 (2000) 632-636.

[7] B.J. Harder, J. Ramirez-Rico, J. Almer, K.N. Lee, K.T. Faber, Chemical and mechanical consequences of environmental barrier coating exposure to calcium-magnesium-aluminosilicate, J. Am. Ceram. Soc. 94 (2011) S178-S185.

[8] K. M. Grant, S. Kramer, J.P.A. Lofvander, C.G. Levi, CMAS Degradation of environmental barrier coatings, Surf. Coat. Technol. 202 (2007) 653-57.

[9] B.J. Harder, J. Almer, C.M. Weyant, K.N. Lee, K.T. Faber, Residual stress analysis of multilayer environmental barrier coatings, J. Am. Ceram. Soc. 92 (2009) 452-459.

[10] K.N. Lee, D.S. Fox, N.P. Bansal, Rare earth silicate environmental barrier coatings for $\mathrm{SiC} / \mathrm{SiC}$ composites and $\mathrm{Si}_{3} \mathrm{~N}_{4}$, J. Eur. Ceram. Soc. 25 (2005) 1705-1715. 
[11] K. N. Lee, Environmental Barrier Coatings for $\mathrm{SiC}_{\mathrm{f}} / \mathrm{SiC}$; in N. P. Bansal, J. Lamon (Eds.) Ceramic Matrix Composites: Materials, Modelling and Technology, John Wiley \& Sons, Hoboken, NJ (2014).

[12] F. Stolzenburg, J. Almer, K.N. Lee, K.T. Faber, Stresses in ytterbium silicate multilayer environmental barrier coatings, Adv. X-ray Anal. 55 (2011) 106-115.

[13] F. Stolzenburg, Residual Stresses and Phase Transformations in Ytterbium Silicate Environmental Barrier Coatings, PhD Dissertation, Northwestern University, Evanston, IL, USA (2013).

[14] H. Klemm, M. Fritsch, B. Schenk, $28^{\text {th }}$ Int. Conf. on Advanced. Ceram. and Composites, Cocoa Beach, FL, Jan. 25-30 (2004).

[15] N. S. Jacobson, Silica Activity Measurements in the $\mathrm{Y}_{2} \mathrm{O}_{3}-\mathrm{SiO}_{2}$ System and Applications to Modeling of Coating Volatility, J. Am. Ceram. Soc. 97 (2014) 1959-1965.

[16] G. C. C. Costa, N.S. Jacobson, Mass Spectrometric Measurements of the Silica Activity in the $\mathrm{Yb}_{2} \mathrm{O}_{3}-\mathrm{SiO}_{2}$ System and Implications to Assess the Degradation of Silicate-based Coatings in Combustion Environments, Journal of the European Ceramic Society, in press.

[17] N.L. Ahlborg, D. Zhu, Calcium-magnesium aluminosilicate (CMAS) reactions and degradation mechanisms of advanced environmental barrier coatings, Surf. Coat. Technol. 237 (2013) 79-87.

[18] K.M. Grant, S. Krämer, G.G.E. Seward, C.G. Levi, Calcium-magnesium-alumino-silicate interaction with yttrium monosilicate environmental barrier coatings, J. Am. Ceram. Soc. 93 (2010) $1-8$.

[19] C.G. Levi, J.W. Hutchinson, M.-H. Vidal-Setif, C.A. Johnson, Environmental degradation of thermal-barrier coatings by molten deposits, MRS Bull. 37 (2012) 932-941. 
[20] D.L. Poerschke, C.G. Levi, Effects of cation substitution and temperature on the interaction between thermal barrier oxides and molten CMAS, J. Euro. Ceram. Soc. 35 (2015) 681-91. [21] M.P. Borom, C.A. Johnson, L. Peluso, "Role of environmental deposits and operating surface temperature in spallation of air plasma sprayed thermal barrier coatings, Surf. Coat. Technol. 86-87 (1996) 116-126.

[22] P.S. Prevey, X-ray diffraction characterization of crystallinity and phase composition in plasma-sprayed hydroxyapatite coatings, J. Spray Technol. 9 (2000) 369-376.

[23] S. Krämer, J. Yang, C.G. Levi, Infiltration-inhibiting reaction of gadolinium zirconate thermal barrier coatings with CMAS melts, J. Am. Ceram. Soc. 91 (2008) 576-583. [24] P. Hartman, W.G. Perdow, On the relations between structure and morphology of crystals. III, Acta Cryst. 18 (1955) 535-529.

[25] W. Braue, Environmental stability of the YSZ layer and the YSZ/TGO interface of an inservice EB-PVD coated high pressure turbine blade, J. Mat. Sci. 44 (2009) 1664-1675.

[26] G. Witz, V. Shklover, W Steurer, S. Bachegowda, H.-P. Bossmann, High-temperature interaction of yttria-stabilized zirconia coatings with $\mathrm{CaO}-\mathrm{MgO}-\mathrm{Al}_{2} \mathrm{O}_{3}-\mathrm{SiO}_{2}$ (CMAS) deposits, Surf. Coat. Technol. 265 (2015) 244-249.

[27] W. Braue, P. Mechnich, Recession of an EB-PVD YSZ coated turbine blade by $\mathrm{CaSO}_{4}$ and Fe, Ti-Rich CMAS type deposits, J. Am. Ceram. Soc. 94 (2011) 4483-4489.

[28] A.D. Gledhill, K.M. Reddy, J.M. Drexler, K. Shinoda, S. Sampath, N.P. Padture, Mitigation of damage from molten fly ash to air-plasma sprayed thermal barrier coatings, Mat. Sci. Eng. A 528 (2011) 7214-7221. 
[29] J.M. Drexler, L. Ortiz, N.P. Padture, Composition effects of thermal barrier coating ceramics on their interaction with molten Ca-Mg-Al-Silicate (CMAS) glass, Acta Mat. 60 (2012) $5437-5447$. 


\section{List of Figure Captions}

Figure 1 - Crystalline weight $\% \mathrm{Yb}_{2} \mathrm{SiO}_{5}$ and $\mathrm{Yb}_{2} \mathrm{Si}_{2} \mathrm{O}_{7}$ in samples of $\mathrm{Yb}_{2} \mathrm{SiO}_{5}$ and $\mathrm{Yb}_{2} \mathrm{Si}_{2} \mathrm{O}_{7}$ mixed with $30 \mathrm{wt} \% \mathrm{CMAS}$ as a function of time at $1300^{\circ} \mathrm{C}$. Both samples were $100 \%$ crystalline before heating. Errors in phase fractions are approximately $\pm 3.5 \mathrm{wt} \%$.

Figure 2 - Theta - $2 \theta$ X-ray diffraction pattern of a $70 \mathrm{wt} \% \mathrm{Yb} 2 \mathrm{SiO} 5 / 30 \mathrm{wt} \%$ CMAS powders heated for 96 hours at $1300^{\circ} \mathrm{C}$. Spectrum from a) $20-45^{\circ}$ b) $25-35^{\circ}$. All unlabeled peaks in as-mixed are $\mathrm{Yb} 2 \mathrm{SiO}$. Peaks marked $*$ are $\mathrm{Ca}_{2} \mathrm{Yb}_{8}\left(\mathrm{SiO}_{4}\right)_{6} \mathrm{O}_{2}$ silicate oxyapatite. In the as-mixed sample, the alumina peaks at $25^{\circ}$ and $38^{\circ}$ overlap with $\mathrm{Yb} 2 \mathrm{SiO}_{5}$ peaks.

Figure 3 - SEM image of $70 \mathrm{wt} \% \mathrm{Yb}_{2} \mathrm{SiO} 5$ powder mixed with $30 \mathrm{wt} \% \mathrm{CMAS}$ after 4 hours at $1300^{\circ} \mathrm{C}$. Needle-like hexagonal precipitates of a second phase have formed throughout the entire sample.

Figure 4 - a) SEM cross-sectional backscattered image of bulk Yb2SiO5 with a CMAS well after 4 hours at $1300^{\circ} \mathrm{C}$. The lighter phase at the bottom of the image is $\mathrm{Yb}_{2} \mathrm{SiO}_{5}$, the dark phase is CMAS and the needle-like precipitates are a reaction product of CMAS and $\mathrm{Yb}_{2} \mathrm{SiO}$. b) Compositional EDS maps showing $\mathrm{Ca}, \mathrm{Si}$ and $\mathrm{Yb}$ in the CMAS and needle-like precipitates approximately $100 \mu \mathrm{m}$ from the CMAS/Yb2SiO5 interface inafter 4 hours at $1300^{\circ} \mathrm{C}$. c) SAED pattern of a $\mathrm{Ca}_{2} \mathrm{Yb}_{8}\left(\mathrm{SiO}_{4}\right)_{6} \mathrm{O}_{2}$ FIB needlelike precipitates.

Figure 5 - Theta - $2 \theta$ X-ray diffraction pattern of a $70 \mathrm{wt} \% \mathrm{Yb}_{2} \mathrm{Si}_{2} \mathrm{O} 7 / 30 \mathrm{wt} \%$ CMAS powdersed-sample heated for 96 hours at $1300^{\circ} \mathrm{C}$. Spectrum from a) $20-45^{\circ}$ b) $25-35^{\circ}$ All unlabeled peaks in as-mixed are $\mathrm{Yb} 2 \mathrm{Si}_{2} \mathrm{O} 7$. Locations marked $*$ are $\mathrm{Ca}_{2} \mathrm{Yb}_{8}\left(\mathrm{SiO}_{4}\right)_{6} \mathrm{O}_{2}$ silicate oxyapatite.

Figure 6 - a) SEM cross-sectional image of bulk $\mathrm{Yb}_{2} \mathrm{Si}_{2} \mathrm{O} 7$ sample with a CMAS well after a 96 hours at $1300^{\circ} \mathrm{C}$. Well is epoxy-filled except for void in lower-right corner; CMAS glass has infiltrated sample porosity. Black outline denotes top of region shown in b) an SEM image of bulk $\mathrm{Yb}_{2} \mathrm{Si}_{2} \mathrm{O} 7$ sample area between the bottom of the CMAS well and the sample base after 96 hours at $1300^{\circ} \mathrm{C}$. c) Higher 
magnification of $b$ ) showing gray minority phase of $\mathrm{Ca}_{2} \mathrm{Yb}_{8}\left(\mathrm{SiO}_{4}\right)_{6} \mathrm{O}_{2}$ precipitates. d) Higher magnification of region approximately $1 \mathrm{~mm}$ from well showing white minority phase of $\mathrm{Yb}_{2} \mathrm{SiO}_{5}$ particles.

Figure 7 - Measured activity of $\mathrm{SiO}_{2}$ and calculated activity of $\mathrm{Yb}_{2} \mathrm{O}_{3}$ based upon reference 16 . 


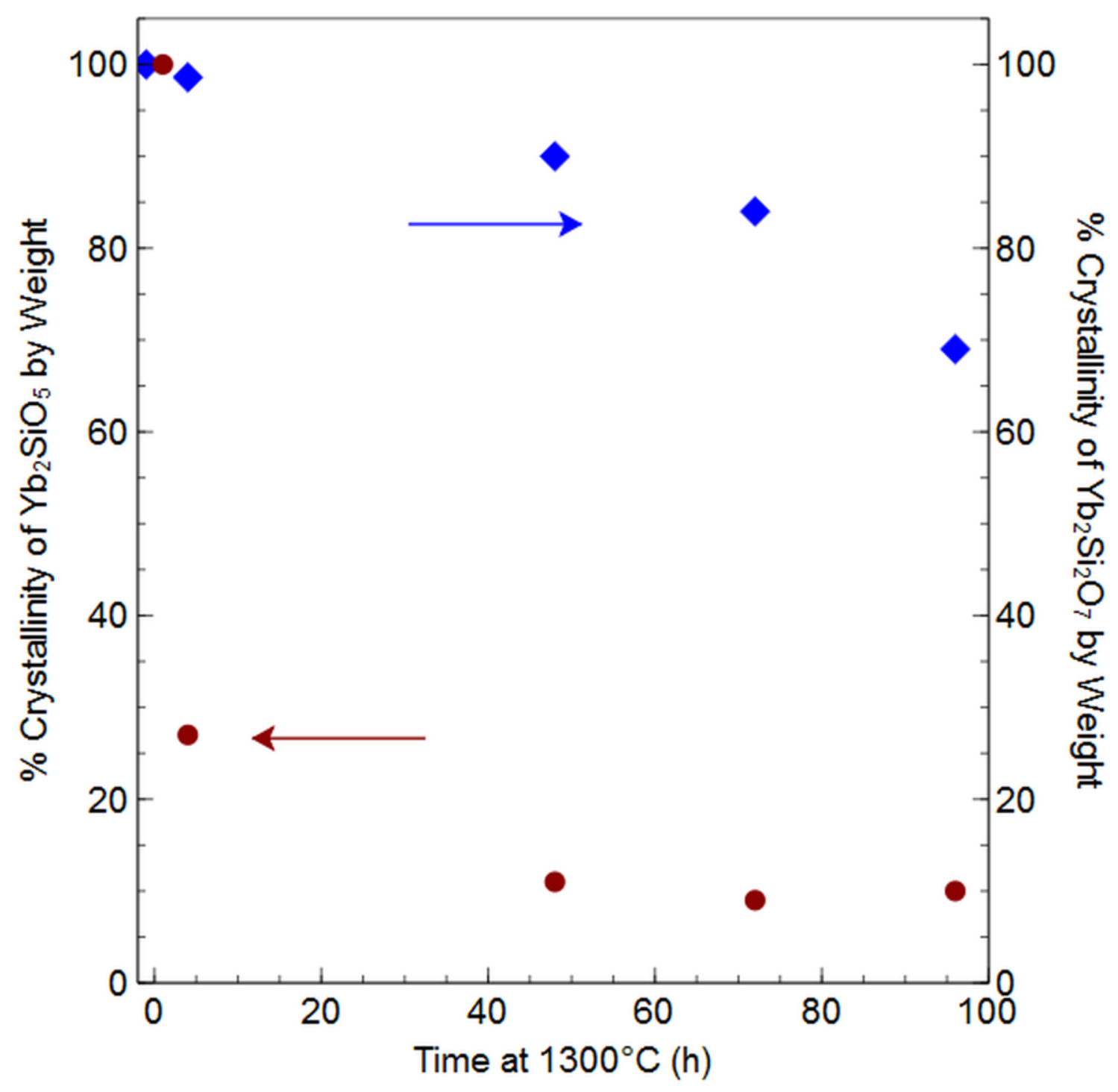

Figure 1 

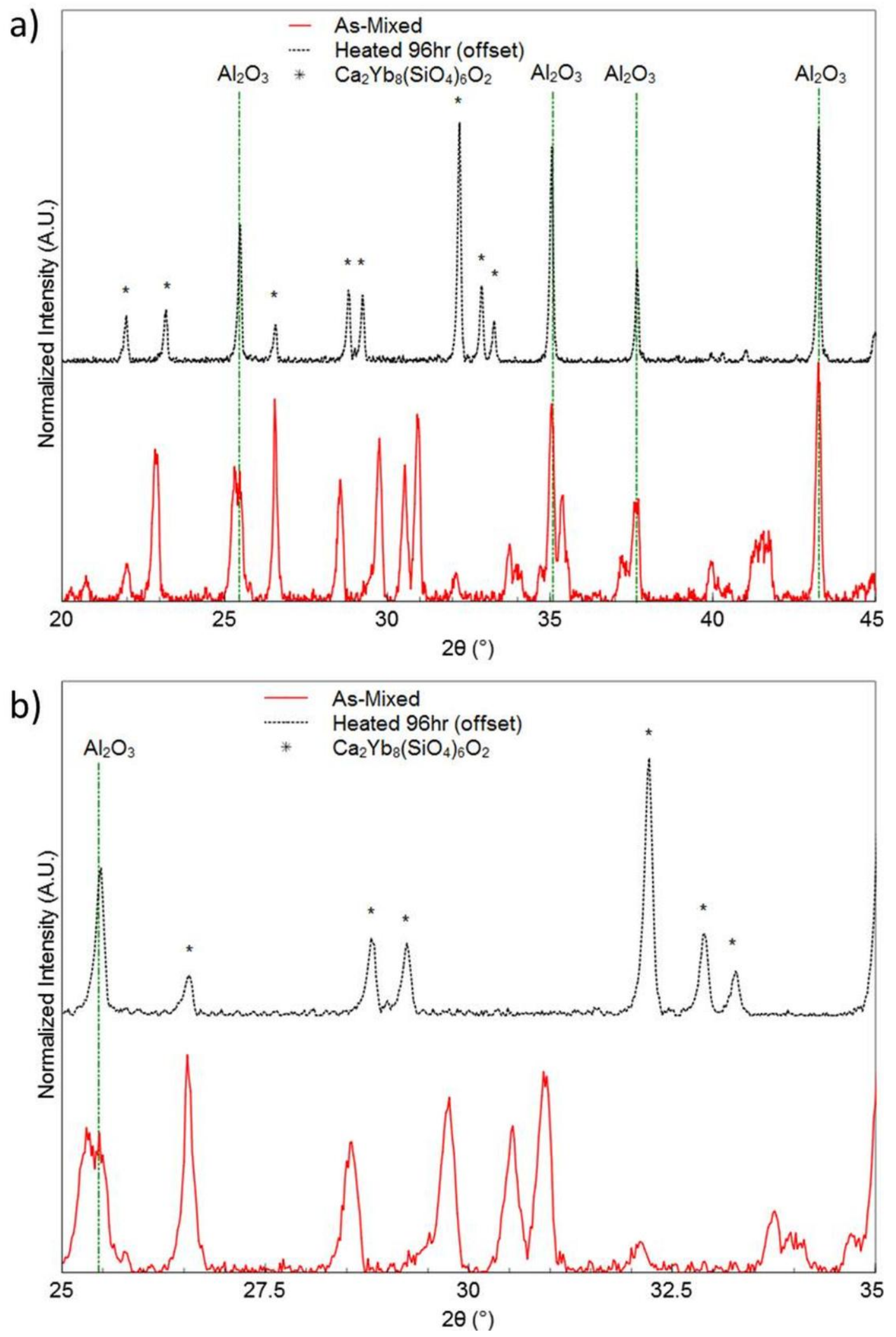

Figure 2 


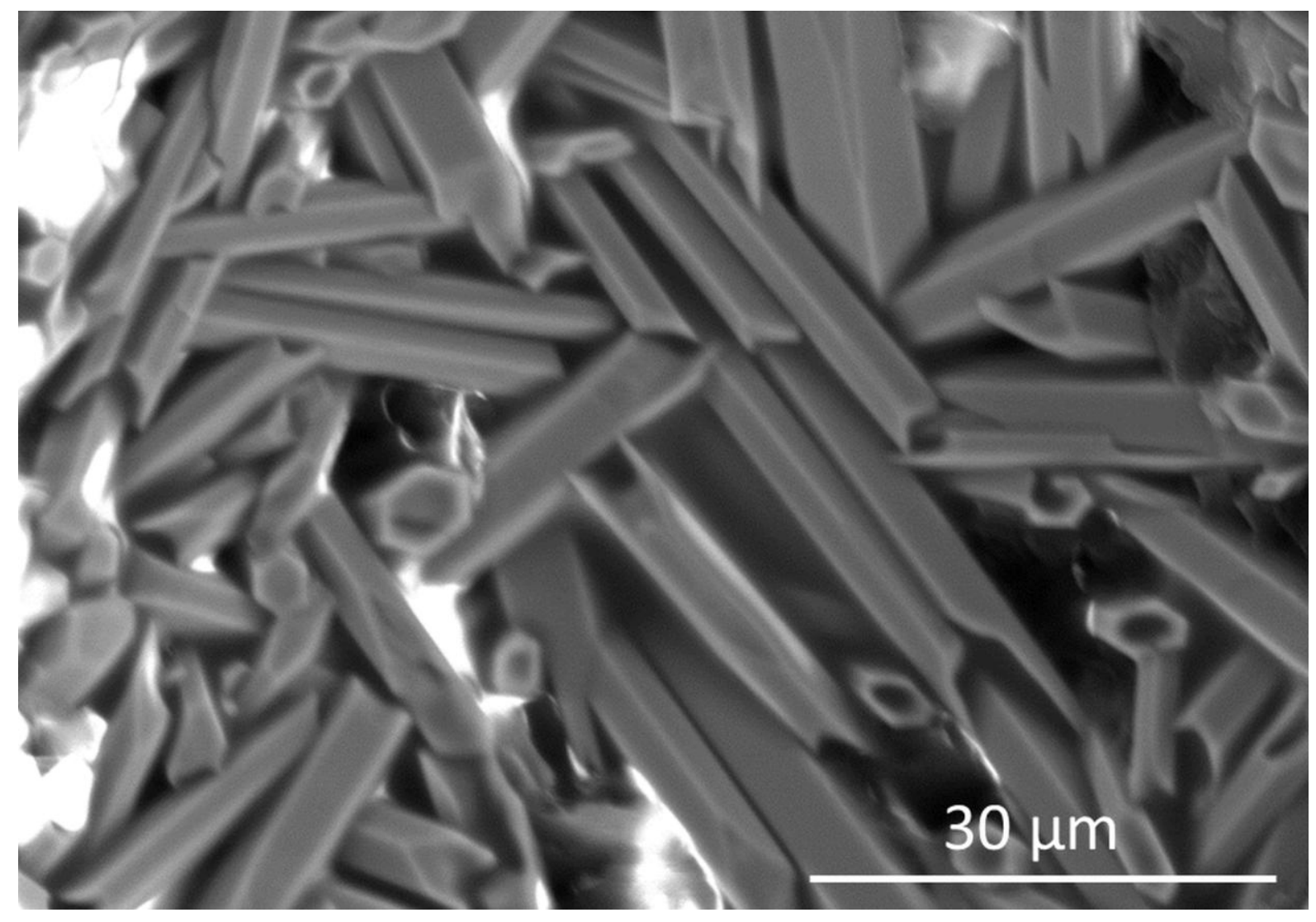

Figure 3 


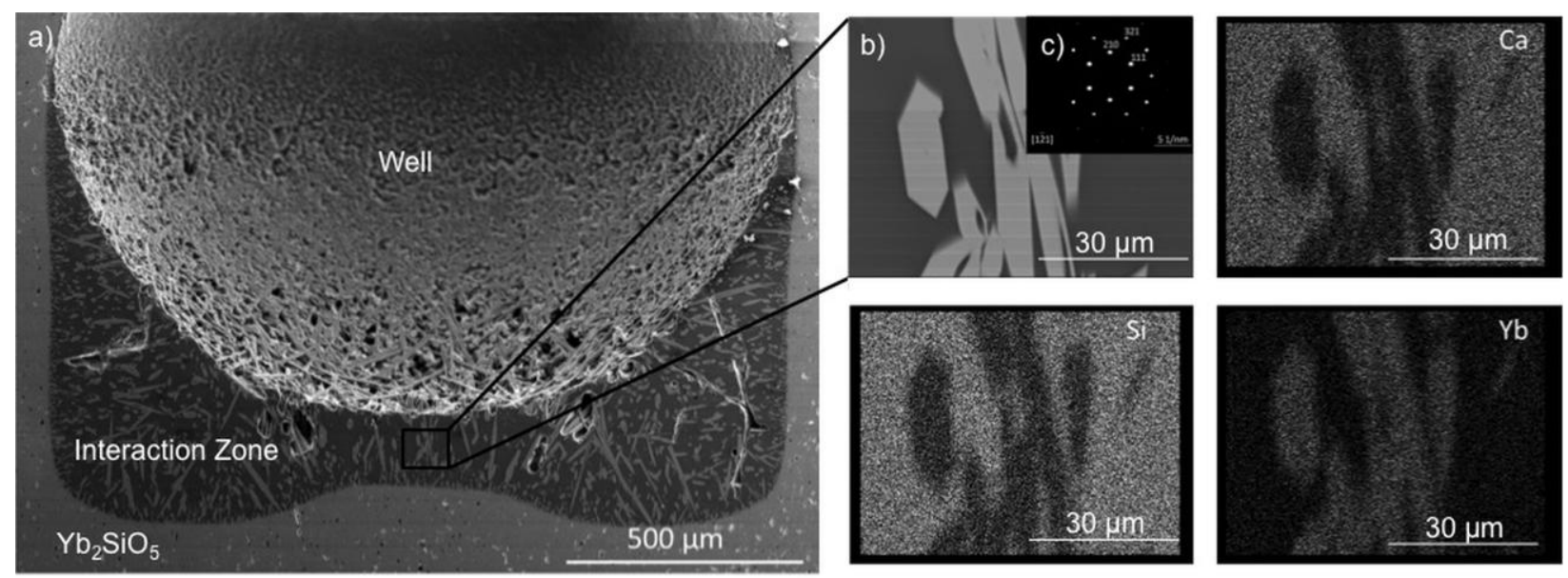

Figure 4 

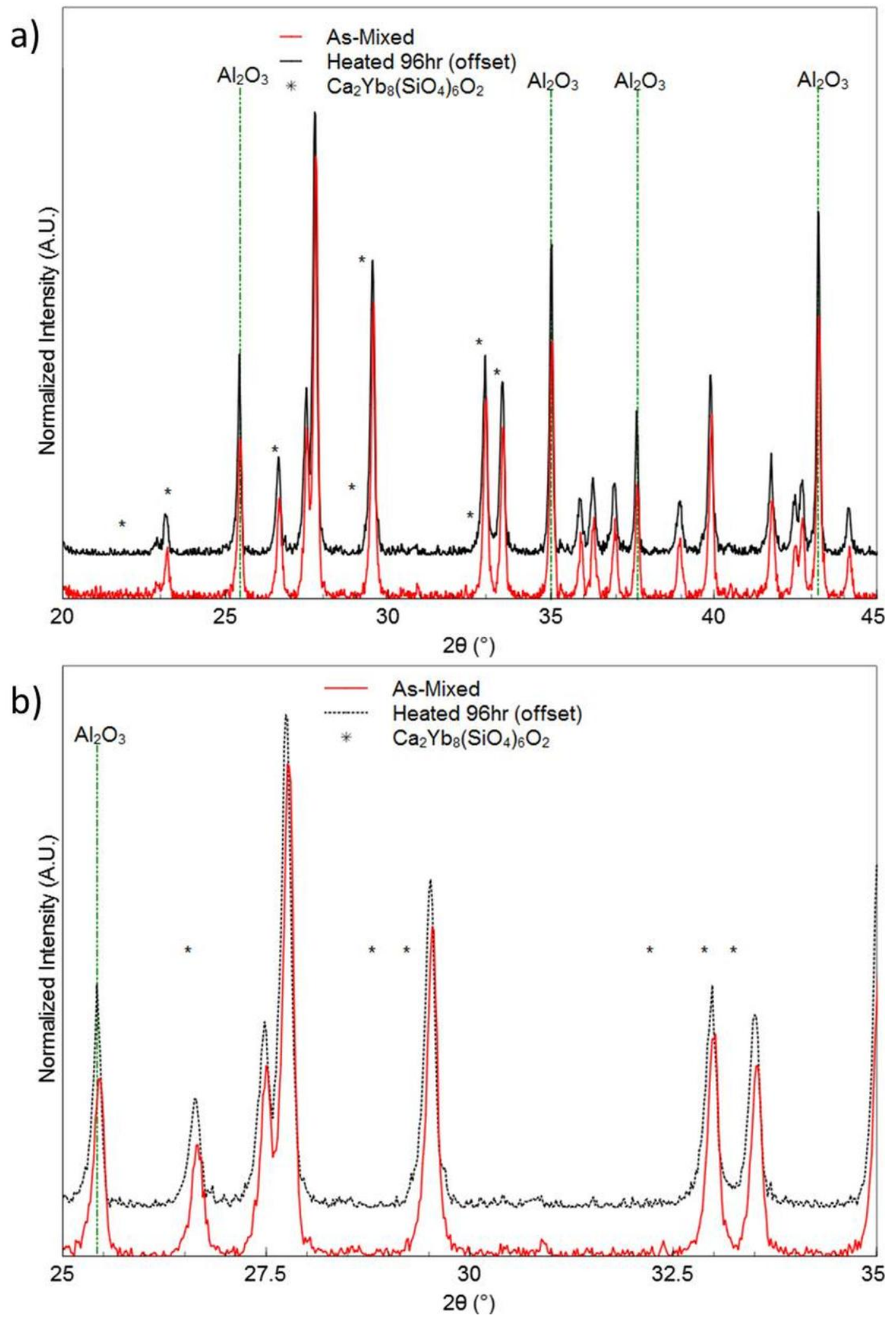

Figure 5 

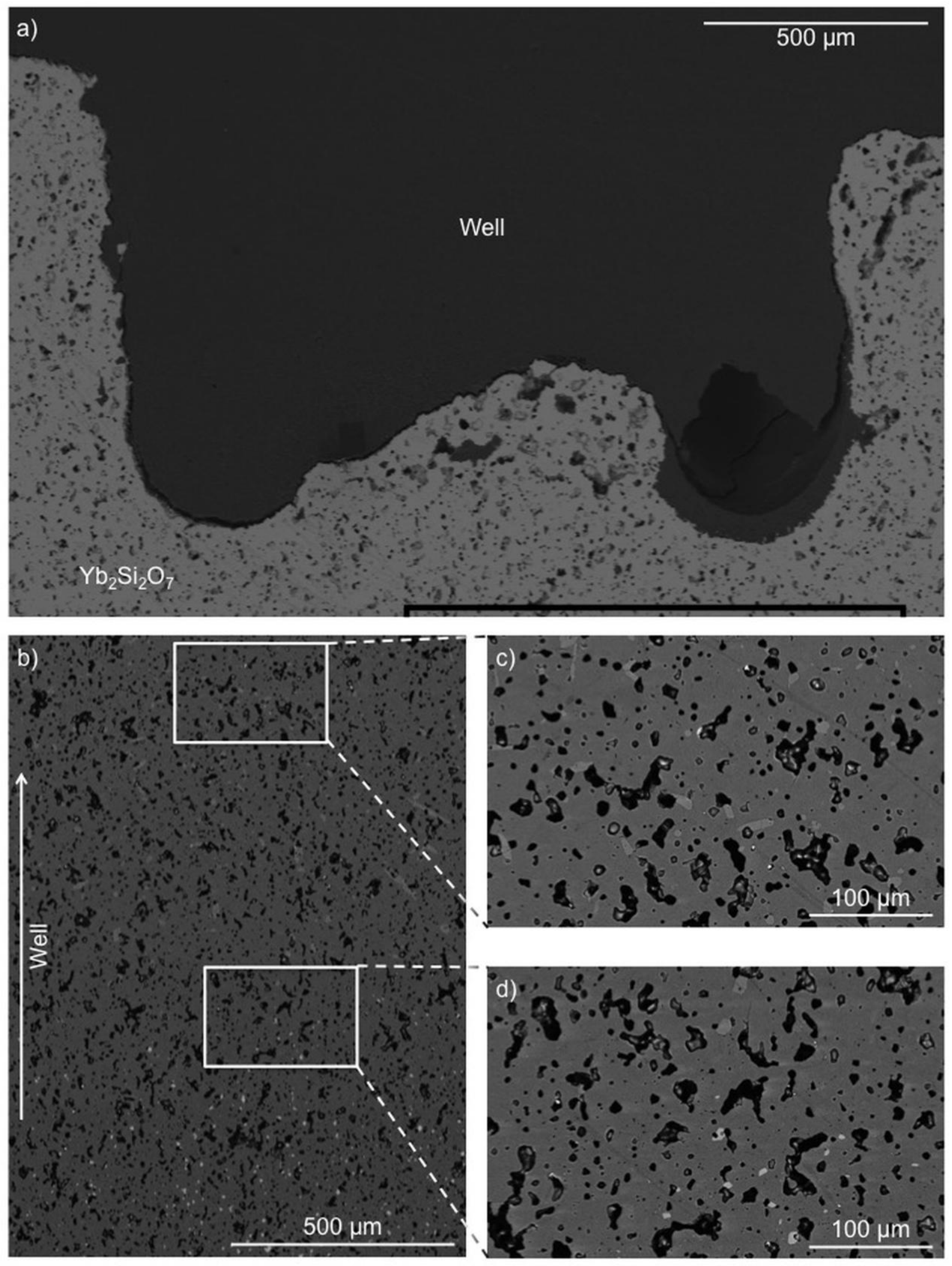

Figure 6 


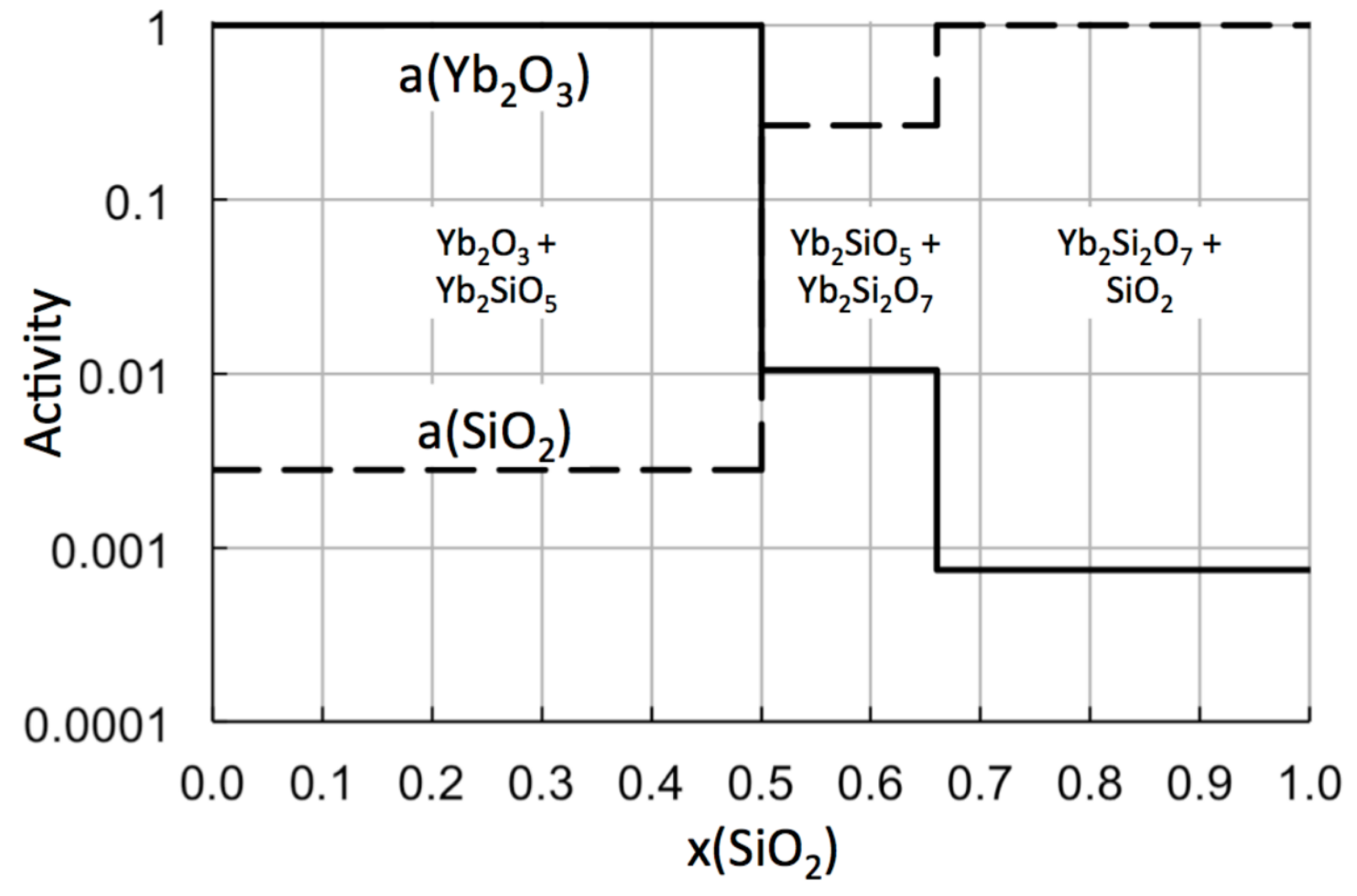

Figure 7 
Table I. Reference intensity ratios (RIRs) for select materials as measured with respect to the (113) $\mathrm{Al}_{2} \mathrm{O}_{3}$ reflection

\begin{tabular}{llll} 
Phase & Reflection & Peak Position $\left(^{\circ}\right)$ & RIR \\
\hline $\mathrm{Yb}_{2} \mathrm{Si}_{2} \mathrm{O}_{7}$ & $(021)$ & 27.9 & 4.1 \\
$\mathrm{Yb}_{2} \mathrm{SiO}_{5}$ & $(\overline{4} 02)$ & 31.0 & 1.3 \\
\hline
\end{tabular}


Table II. Summary of precipitate and glass compositions determined by EDS in a $\mathrm{Yb}_{2} \mathrm{SiO}_{5} / \mathrm{CMAS}$ sample approximately $100 \mu \mathrm{m}$ from the interface after heat treatment at $1300^{\circ} \mathrm{C}$ for 4 hours, compared to $\mathrm{CaYb}_{4}\left(\mathrm{SiO}_{4}\right)_{3} \mathrm{O}$ and starting CMAS compositions. Each composition is an average of 10 measurements. All values are reported in mol\% oxide.

\begin{tabular}{|l|l|l|l|l|}
\hline Oxide & $\begin{array}{l}\text { Measured } \\
\text { composition } \\
\text { of } \\
\text { precipitates }\end{array}$ & $\mathrm{Ca}_{2} \mathrm{Yb}_{8}\left(\mathrm{SiO}_{4}\right)_{6} \mathrm{O}_{2}$ & $\begin{array}{l}\text { Measured } \\
\text { composition } \\
\text { of glass }\end{array}$ & $\begin{array}{l}\text { CMAS } \\
\text { (starting } \\
\text { composition) }\end{array}$ \\
\hline $\mathrm{CaO}$ & 12.2 & 12.5 & 22.9 & 33 \\
\hline $\mathrm{MgO}$ & - & - & 9.8 & 9 \\
\hline $\mathrm{AlO}$ & - & - & 12.9 & 13 \\
\hline $\mathrm{YbO}_{1.5}$ & 46.8 & 50 & 6.4 & - \\
\hline $\mathrm{SiO}_{2}$ & 41.0 & 37.5 & 48.0 & 45 \\
\hline
\end{tabular}

